\section{ISOLATION AND CHARACTERIZATION OF A NEW ANTIBIOTIC, DIOXAPYRROLOMYCIN, RELATED TO PYRROLOMYCINS}

Notes

\author{
Hikaru NaKamura, Kazuro Shiom, \\ Hironobu IINUma, Hiroshi Naganawa, \\ Tamami Obata, Tomio Takeuchi \\ and HAMAO UMEZAWA \\ Institute of Microbial Chemistry, \\ 3-14-23 Kamiosaki, Shinagawa-ku, \\ Tokyo 141, Japan \\ YASUO TAKEUChI \\ Pharmacology and Toxicology Laboratories, \\ Meiji Seika Kaisha, Ltd., \\ 760 Morooka-cho, Kohoku-ku, \\ Yokohama 222, Japan

\section{YOICHI IITAKA} \\ Faculty of Pharmaceutical Sciences, \\ University of Tokyo, \\ 7-3-1 Hongo, Bunkyo-ku, Tokyo 113, Japan
}

(Received for publication February 5, 1987)

In the course of screening for new antibiotics, we have isolated dioxapyrrolomycin (1), which inhibits the growth of Gram-positive bacteria, some Gram-negative bacteria and some fungi, from cultured broth of Streptomyces sp. MG796AF7. The structure of the $N$-methyl derivative (2) was determined by X-ray crystallographic analysis to be (4S)-6,8-dichloro-4-(4,5-dichloro-1methyl-3-nitro-2-pyrrolyl)-1,3-benzodioxane (Fig. 1). In this report, the production, isolation, physico-chemical properties, structure and biolo-

Fig. 1. Structures of dioxapyrrolomycin and its $N$-methyl derivative.

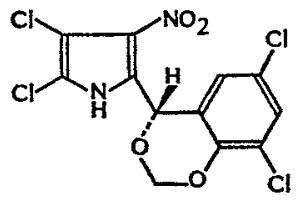

Dioxapyrrolomycin (1)

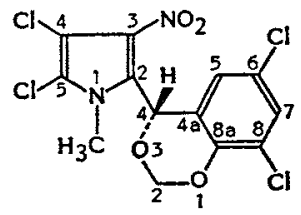

N-Methyldioxapyrrolomycin (2) gical properties of $\mathbf{1}$ are reported.

A strain which produced 1 was isolated from a garden soil sample collected in our institute and classified as Streptomyces sp. MG796-AF7 (strain number in the Institute of Microbial Chemistry, MG796-AF7). The strain was precultured in a 500-ml Erlenmeyer flask containing $110 \mathrm{ml}$ of a medium consisting of Bacto-Soytone (Difco) $1.0 \%$, galactose $2.0 \%$, corn steep liquor (Nippon Shokuhin Kako Co.) $0.5 \%$, dextrin $2.0 \%,\left(\mathrm{NH}_{4}\right)_{2} \mathrm{SO}_{4} 0.2 \%, \mathrm{CaCO}_{3} 0.2 \%$, silicone oil (Shin-Etsu Chemical Industry, KM-70) $0.03 \%$, pH 7.4 before sterilization. Incubation was on a rotary shaker at $27^{\circ} \mathrm{C}$ for 5 days. Two $\mathrm{ml}$ of the precultured broth was inoculated into each 500-ml Erlenmeyer flask containing $110 \mathrm{ml}$ of the same medium; the flasks were then shaken at $27^{\circ} \mathrm{C}$ for 4 days.

The culture filtrate (5.8 liters) thus obtained was adjusted to $\mathrm{pH} 8.0$ and extracted with BuOAc. The mycelium was extracted with $\mathrm{MeOH}$, the extract concd and the concentrate transferred into BuOAc. The BuOAc extracts of the culture filtrate and the mycelium were combined and concd under reduced pressure to give a brownish oil (1.22 g). The residual oil was dissolved in $\mathrm{CHCl}_{3}$ and charged on a silica gel column (Merck, Art 7734, $70 \mathrm{~g}$ ). The column was developed with $\mathrm{CHCl}_{3}$ and the eluate concd under reduced pressure to give a yellow powder $(157 \mathrm{mg})$. This was dissolved in hot EtOH and kept in the refrigerator to yield $59 \mathrm{mg}$ of pale yellow crystals of $1, \operatorname{mp} 200 \sim 207^{\circ} \mathrm{C},[\alpha]_{\mathrm{D}}^{25}-110^{\circ}$ (c 0.5, EtOH).

Antibiotic 1 is soluble in $\mathrm{MeOH}, \mathrm{Me}_{2} \mathrm{CO}$, EtOAc and ethyl ether but hardly soluble in hexane and water. It gives negative reaction with ninhydrin, but positive reaction with $\mathrm{KMnO}_{4}$ and Rydon-Smith reagent.

The molecular formula of 1 was established to be $\mathrm{C}_{12} \mathrm{H}_{6} \mathrm{~N}_{2} \mathrm{O}_{4} \mathrm{Cl}_{4}$ (MW 384.00) by electron impact mass spectra (EI-MS) $\left(\mathrm{M}^{+} m / z\right.$ 382, 384, 386, 388 and 390). Elemental Anal calcd: C 37.53, H 1.57, N 7.30, Cl 36.93; found: C 37.75, $\mathrm{H} 1.77, \mathrm{~N} 6.94, \mathrm{Cl} 42.88$. UV $\lambda_{\max }^{\mathrm{MeOH}} \mathrm{nm}(\log \varepsilon)$ 211 (4.44), 278 (3.78) and 320 (3.65). UV $\lambda_{\max }^{0.01 \mathrm{~N} \mathrm{HC1}} \mathrm{nm}(\log \varepsilon) 211(4.44), 273$ (3.85) and 321 (3.54). UV $\underset{\max }{0.01 \mathrm{NaOH}} \mathrm{nm}(\log \varepsilon) 212(4.48), 296$ 
Fig. 2. IR spectrum of dioxapyrrolomycin (KBr).

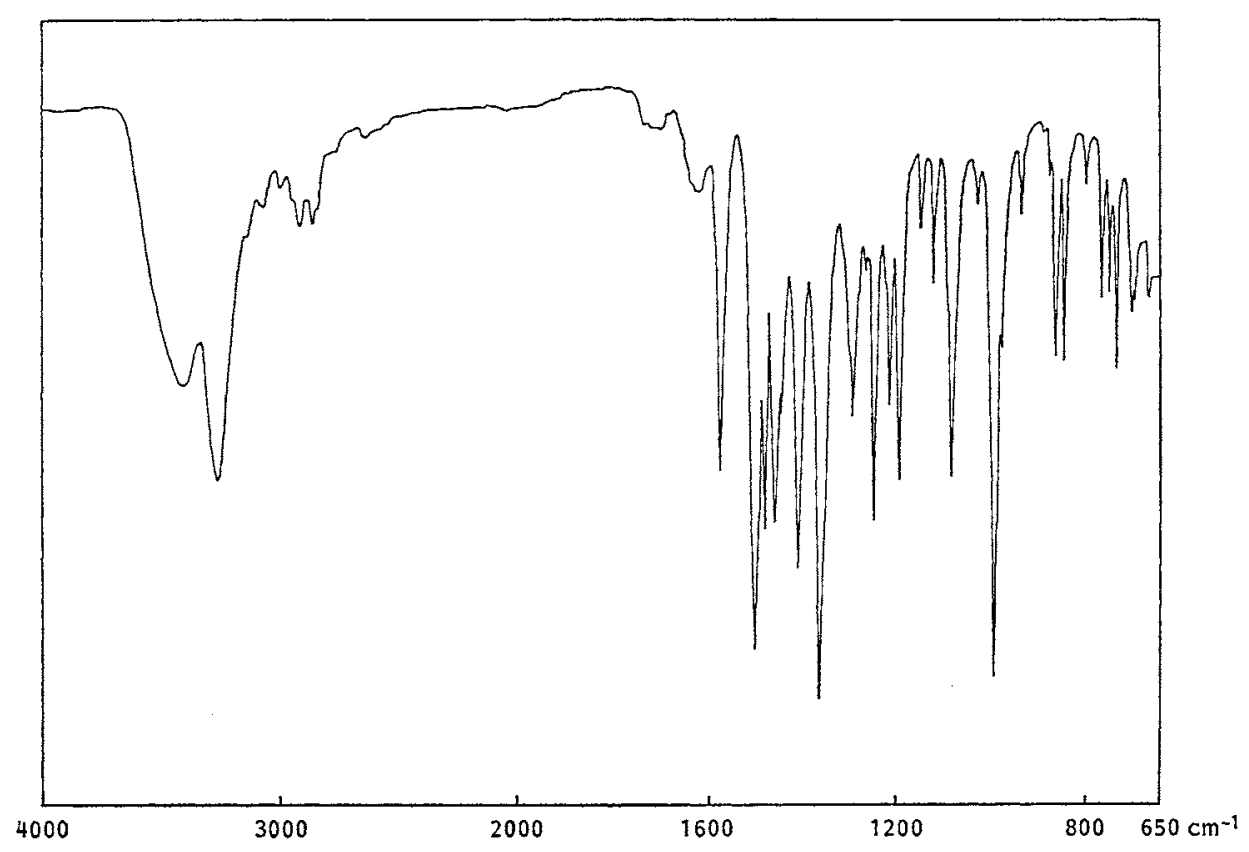

(3.84) and 319 (3.95). The IR spectrum is shown in Fig. 2. After structure determination, the signals of the ${ }^{1} \mathrm{H}$ NMR $\left(400 \mathrm{MHz}, \mathrm{MeOH}-d_{4}\right)$ spectrum were assigned as follows (all protons connect to benzodioxane ring): $\delta 7.39(1 \mathrm{H}$, d, $\left.J_{5,7}=2.8 \mathrm{~Hz}, 7-\mathrm{H}\right), 6.85\left(1 \mathrm{H}, \mathrm{d}, J_{5,7}=2.8 \mathrm{~Hz}\right.$, $5-\mathrm{H}), 6.83(1 \mathrm{H}, \mathrm{s}, 4-\mathrm{H}), 5.52\left(1 \mathrm{H}, \mathrm{d}, J_{\mathrm{a}, \mathrm{b}}=6.4 \mathrm{~Hz}\right.$ and $\left.2-\mathrm{H}_{2}\right)$ and $5.44\left(1 \mathrm{H}, \mathrm{d}, J_{\mathrm{a}, \mathrm{b}}=6.4 \mathrm{~Hz}, 2-\mathrm{H}_{2}\right)$. The ${ }^{13} \mathrm{C}$ NMR $\left(100 \mathrm{MHz}, \mathrm{MeOH}-d_{4}\right)$ signals were as follows: $\delta 149.2(\mathrm{~s}), 132.4(\mathrm{~s}), 131.1(\mathrm{~s})$, 130.5 (d), 127.4 (s), 126.1 (d), 125.5 (s), 124.0 (s), $117.4(\mathrm{~s}), 106.3(\mathrm{~s}), 92.3(\mathrm{t})$ and $70.4(\mathrm{~d})$.

Treatment of 1 with diazomethane gave the $N$ methylated derivative (2): MP $142 \sim 143^{\circ} \mathrm{C}$; $[\alpha]_{\mathrm{D}}^{25}-20^{\circ}$ ( $c 1.0$, benzene); EI-MS $\mathrm{M}^{+} m / z 396$, 398, 400, 402 and 404. The ${ }^{1} \mathrm{H}$ and ${ }^{13} \mathrm{C}$ NMR spectra are shown in Table 1. The structure of 2 was determined by X-ray crystallographic analysis as follows. Compound 2 was recrystallized in ethyl ether to give well developed pyramidal crystals. An X-ray specimen $(0.1 \times$ $0.4 \times 0.15 \mathrm{~mm}$ in size) was mounted on a Philips PW1100 diffractometer and the intensities were measured using $\mathrm{CuK} \alpha$ radiation monochromated by a graphite plate.

Crystal data: $N$-Methyl derivative of dioxapyrrolomycin, $\mathrm{C}_{13} \mathrm{H}_{8} \mathrm{~N}_{2} \mathrm{O}_{4} \mathrm{Cl}_{4}$, MW (398.0). Orthorhombic, space group $\mathrm{P} 2{ }_{1} 2_{1} 2, Z=4, D_{\text {eale }}=$
Table $1 .{ }^{13} \mathrm{C}$ and ${ }^{1} \mathrm{H}$ NMR chemical shifts (ppm) of $N$-methyldioxapyrrolomycin.

\begin{tabular}{|c|c|c|}
\hline & Carbon & Proton \\
\hline \multicolumn{3}{|c|}{ Benzodioxane moiety } \\
\hline C-2 & $92.3 \mathrm{t}$ & $\begin{array}{l}5.38 \mathrm{~d}, 5.63 \mathrm{~d} \\
(J=6.0)\end{array}$ \\
\hline$C-4$ & $68.9 \mathrm{~d}$ & $7.10 \mathrm{brs}$ \\
\hline$C-4 a$ & $123.2 \mathrm{~s}$ & - \\
\hline C-5 & $124.2 \mathrm{~d}$ & $\begin{array}{l}6.72 \mathrm{~d} \\
(J=2.4)\end{array}$ \\
\hline $\mathrm{C}-6$ & $127.3 \mathrm{~s}$ & - \\
\hline C-7 & $130.0 \mathrm{~d}$ & $\begin{array}{l}7.35 \mathrm{~d} \\
(J=2.4)\end{array}$ \\
\hline C-8 & $123.1 \mathrm{~s}$ & - \\
\hline $\mathrm{C}-8 \mathrm{a}$ & $147.6 \mathrm{~s}$ & - \\
\hline \multicolumn{3}{|c|}{ Nitropyrrole moiety } \\
\hline $\mathrm{N}-\mathrm{CH}_{3}$ & $33.7 \mathrm{q}$ & $3.45 \mathrm{~s}$ \\
\hline $\mathrm{C}-2$ & $127.5 \mathrm{~s}$ & - \\
\hline C-3 & $132.6 \mathrm{~s}$ & - \\
\hline C-4 & $106.1 \mathrm{~s}$ & - \\
\hline C-5 & $119.6 \mathrm{~s}$ & - \\
\hline
\end{tabular}

The sample was dissolved in $\mathrm{CDCl}_{3}$ and recorded at $400 \mathrm{MHz}$ and $100 \mathrm{MHz}$ for proton and carbon, respectively (internal reference TMS), Coupling constants $(\mathrm{Hz})$ are in parentheses. Signals were assigned by the aid of ${ }^{1} \mathrm{H}^{-13} \mathrm{C}$ shift correlation spectrum and long range ${ }^{1} \mathrm{H}-{ }^{13} \mathrm{C}$ shift correlation spectrum. 
Table 2. Antimicrobial activities of dioxapyrrolomycin.

\begin{tabular}{|c|c|c|c|c|c|}
\hline Test organisms & Medium* & $\begin{array}{c}\mathrm{MIC} \\
(\mu \mathrm{g} / \mathrm{ml})\end{array}$ & Test organisms & Medium* & $\begin{array}{c}\mathrm{MIC} \\
(\mu \mathrm{g} / \mathrm{ml})\end{array}$ \\
\hline Staphylococcus aureus FDA 209P & a & 1.56 & Pseudomonas aeruginosa A3 & a & $>50$ \\
\hline S. aureus Smith & a & 1.56 & Klebsiella pneumoniae PCI 602 & $\mathrm{a}$ & $>100$ \\
\hline S. aureus MS8710 & a & 1.56 & Mycobacterium smegmatis ATCC 607 & a & 3.12 \\
\hline S. aureus MS9610 & $\mathrm{a}$ & 1.56 & Aeromonas punctata IAM 1646 & $\mathrm{~b}$ & 25 \\
\hline Micrococcus luteus FDA 16 & a & $<0.2$ & A. salmonicida ATCC 14174 & $b$ & 6.25 \\
\hline M. luteus IFO 3333 & a & 0.39 & Aeromonas sp. (KT-444) & b & 6.25 \\
\hline M. luteus PCI 1001 & $\mathrm{a}$ & 1.56 & Vibrio anguillarum $\mathrm{NCMB} 6$ & $\mathrm{~b}$ & 3.12 \\
\hline Bacillus anthracis & $\mathrm{a}$ & 0.78 & Pseudomonas fluorescens & $b$ & 25 \\
\hline B. subtilis NRRL B-558 & a & 0.78 & P. lachrymans & $\mathrm{b}$ & $>50$ \\
\hline B. subtilis PCI 219 & $\mathrm{a}$ & 1.56 & Erwinia aroideae & $b$ & $>50$ \\
\hline B. cereus ATCC 10702 & $\mathbf{a}$ & 1.56 & Candida tropicalis F-1 & $\mathrm{c}$ & $>100$ \\
\hline Corynebacterium bovis 1810 & a & 0.39 & C. pseudotropicalis $\mathrm{F}-2$ & $\mathrm{c}$ & 12.5 \\
\hline Escherichia coli NIHJ & $\mathbf{a}$ & 6.25 & C. albicans 3147 & $\mathrm{c}$ & $>100$ \\
\hline E. coli $\mathrm{K}-12$ & a & 25 & Candida $\mathrm{Yu}-1200$ & $\mathrm{c}$ & $>100$ \\
\hline E. coli ML1629 & $\mathrm{a}$ & $>50$ & C. krusei F-5 & $\mathrm{c}$ & $>100$ \\
\hline Shigella dysenteriae JS11910 & $\mathbf{a}$ & $>50$ & Saccharomyces cerevisiae F-7 & $\mathrm{c}$ & $>100$ \\
\hline S. flexneri $4 \mathrm{~b}$ JS11811 & $\mathrm{a}$ & $>50$ & Cryptococcus neoformans $\mathrm{F}-10$ & $\mathrm{c}$ & 6.25 \\
\hline S. sonnei JS11746 & a & $>50$ & Helminthosporium oryzae & $\mathrm{c}$ & 50 \\
\hline Salmonella typhi $\mathrm{T}-63$ & $\mathrm{a}$ & $>50$ & Piricularia oryzae & $\mathrm{c}$ & 50 \\
\hline S. enteritidis 1891 & a & $>100$ & Pellicularia sasakii & $\mathrm{c}$ & 50 \\
\hline Proteus vulgaris OX19 & a & $>50$ & Xanthomonas citri & $\mathrm{c}$ & 100 \\
\hline P. mirabilis IFM OM-9 & $\mathrm{a}$ & $>50$ & $X$. oryzae & $\mathrm{c}$ & 3.12 \\
\hline P. rettgeri GN 311 & a & $>50$ & Aspergillus niger F-16 & $\mathrm{c}$ & $>100$ \\
\hline P. rettgeri GN466 & $\mathrm{a}$ & 25 & Trichophyton asteroides 429 & $\mathrm{c}$ & 25 \\
\hline Serratia marcescens & $\mathrm{a}$ & $>50$ & T. mentagrophytes & $\mathrm{c}$ & 12.5 \\
\hline
\end{tabular}

a: Mueller-Hinton agar $37^{\circ} \mathrm{C}$, b: Mueller-Hinton agar $27^{\circ} \mathrm{C}$, c: nutrient agar + glucose $1 \%, 27^{\circ} \mathrm{C}$. 
Fig. 3. Molecular structure of $\mathrm{N}$-methyldioxapyrrolomycin.

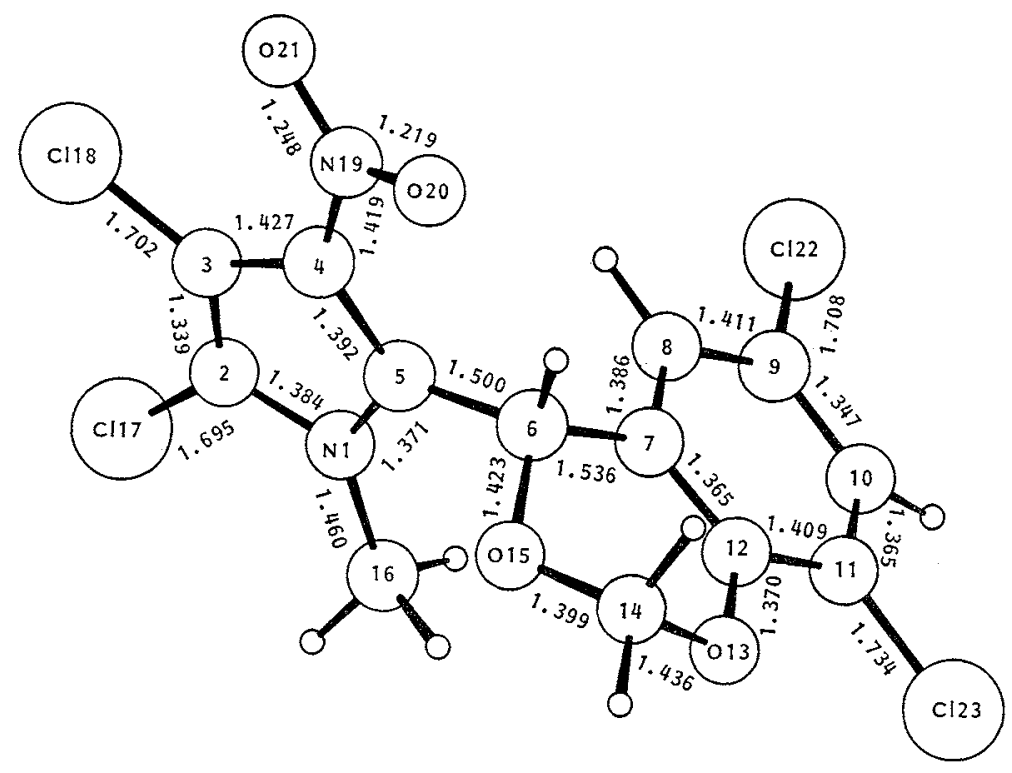

$1.714 \mathrm{gcm}^{-3}, \mu$ for $\mathrm{CuK} \alpha=73.5 \mathrm{~cm}^{-1}$. Lattice constants, $\quad a=8.595(5), \quad b=20.556(11), \quad c=$ 8.728(5) $\AA, U=1542 \AA^{3}$. The 1569 reflections were measured as above the $2 \sigma$ (I) level, within the $2 \theta$ range of $6^{\circ} \sim 156^{\circ}$, out of 1918 theoretically possible ones. The $322 \bar{h} k 1$ Friedel reflections were also measured immediately after the measurement of hkl reflections.

The crystal structure was determined by the direct method and refined by the block-diagonalmatrix least-squares method. All the hydrogen atoms were located on the difference electrondensity map and the structure was refined to an $R$ value of 0.092 . Absolute configuration was determined by the anomalous dispersion method. The dispersion corrections for $\mathrm{CuK} \alpha$ radiation were applied to $\mathrm{Cl}, \mathrm{O}, \mathrm{N}$ and $\mathrm{C}$ atoms. Seventytwo Friedel pairs out of 77 clearly indicated the absolute configuration shown in Fig. 3. Final refinement including dispersion corrections yielded the $R$ value of 0.070 .

The molecular structure, denoting the bond distances, is shown in Fig. $3^{\dagger}$.

+ Atomic coordinates have been deposited with the Cambridge Crystallographic Data-base and the list of $F o$ and $\mathrm{Fc}$ and other data may be obtained from one of the authors (HIKARU NAKAMURA) upon request.
Antibiotic $\mathbf{1}$ is closely related structurally to pyrrolomycins ${ }^{1,2}$, which have chlorinated nitropyrrole and the dichlorophenol ring. The former is different from the latter in its dichlorobenzodioxane moiety instead of the dichlorophenol of the latter.

The antimicrobial activities of $\mathbf{1}$ are shown in Table 2. It inhibited the growth of Grampositive bacteria, some Gram-negative bacteria and some fungi. The $\mathrm{LD}_{50}$ (ip) of 1 in mice was in the range of $125 \sim 250 \mathrm{mg} / \mathrm{kg}$.

\section{Addendum in Proof}

As already reported, this antibiotic is identical with antibiotic Al-R2081 [RengaraJu, S.; S. Narayanan, P. L. Ganju, M. A. Amin, M. R. S. Iyengar, J. Itoh, Y. TAkeuchi, K. Fujita, S. Miyadoh, T. Shomura, M. SezaKi \& M. KoJIMA: A new antibiotic Al-R2081 related to pyrrolomycin B. Meiji Seika Kenkyu Nempo (Scientific Reports of Meiji Seika Kaisha) 24: 48 51, 1985]. Recently, CARTER et al. (CARTER, G. T.; J. A. Nietsche, J. J. Goodman, M. J. Torrey, T. S. Dunne, D. B. Borders \& R. T. Testa: LL-F42248 $\alpha$, a novel chlorinated pyrrole antibiotic. J. Antibiotics 40: 233 236, 1987) reported that antibiotic LL-F $42248 \alpha$ is structurally identical with dioxapyrrolomycin. 


\section{References}

1) Kaneda, M.; S. NaKamura, N. EzaKI \& Y. IITAKA: Structure of pyrrolomycin B, a chlorinated nitro-pyrrole antibiotic. J. Antibiotics $34: 1366 \sim 1368,1981$
2) Koyama, M.; N. Ezaki, T. Tsuruoka \& S. INOUYE: Structural studies on pyrrolomycins C, D and E. J. Antibiotics 36: 1483 1489, 1983 